\title{
Designing and explaining the Quantum Productivity Model in the Ministry of Sport and Youth of the Islamic Republic of Iran
}

\author{
Diseño y explicación del Modelo de Productividad Cuántica en el \\ Ministerio de Deportes y Juventud de la República Islámica de Irán
}

\author{
Babak Azimi Sanavi ${ }^{1 *}$, Mohammad Hosein Razavi², Mahdi Talebpour ${ }^{3}$, Anoushiravan Kazem Nezhad ${ }^{4}$
}

\author{
1 Shomal University, Amol (Iran). \\ 2 Mazandaran University, Babolsar (Iran). \\ 3 Ferdowsi University of Mashhad, Mashhad (Iran). \\ 4 Tarbiat Modares University, Tehran (Iran).
}

\begin{abstract}
This study aimed to design a quantum productivity model in the Iranian Ministry of Sport and Youth. The sample was composed of managers and staff of the Ministry of Sport and Youth of the Islamic Republic of Iran. In the first part of the study, 14 people were interviewed through thematic analysis method. In the second part, 188 people completed the questionnaire. The research instruments were an interview and a questionnaire of quantum productivity elaborated ad hoc. Data analysis was performed with WarpPLS software. After analyzing the content network, coding and screening, 8 main components of quantum productivity were finally extracted. The prediction power of the designed model was analyzed using the coefficient of determination (R2) for the dependent variables, and it was concluded that the structural model of the present study has sufficient predictive power. Considering these results, it is recommended the use of this quantum productivity model in sports organizations.

Keywords: quantum productivity, content analysis, quantum skills, sport management.
\end{abstract}

\section{Introduction}

Nowadays, fast and continuous changes make the world complex, unstable and unpredictable. In such a world, managers' abilities to plan, organize, direct and control are increasingly compromised (Shelton \& Darling, 2001). In the literature of management, it has been presented a new paradigm in the field of organization and management, a paradigm known as quantum theory. Research in the realm of psychology, biology and neurology shows that humans are actually quantum beings. Although every human being seems to be a material being, it also has an intangible and immaterial dimensions (called mind, consciousness or spirit), that appear to be influenced by quantum principles.

Development of new scientific principles requires knowledge of management techniques in modern organizations, as these technologies and principles provide a new

Dirección para correspondencia [Correspondence address]: Babak Azimi Sanavi. Shomal University, Amol (Iran). E-mail: babak.azimi777@gmail. com
Resumen: Este estudio tuvo como objetivo diseñar un modelo de productividad cuántica en el Ministerio de Deporte y Juventud de Irán. La muestra estuvo compuesta por gerentes y personal del Ministerio de Deportes y Juventud de la República Islámica de Irán. En la primera parte del estudio, 14 personas fueron entrevistadas a través del método de análisis temático. En la segunda parte, 188 personas completaron el cuestionario. Los instrumentos de investigación fueron una entrevista y un cuestionario de productividad cuántica elaborado ad hoc. El análisis de los datos fue realizado con el software WarpPLS. Después de analizar la red de contenido, la codificación y screening, finalmente se extrajeron 8 componentes principales de productividad cuántica. El poder de predicción del modelo diseñado se analizó utilizando el coeficiente de determinación (R2) para las variables dependientes, y se concluyó que el modelo estructural del presente estudio tiene suficiente poder predictivo. Teniendo en cuenta estos resultados, se recomienda el uso de este modelo de productividad cuántica en organizaciones deportivas. Palabras clave: productividad cuántica, análisis de contenido, habilidades cuánticas, gestión deportiva. metaphor for organizational life and management work. The importance and the effectiveness of the interdisciplinary approach in addressing many complex issues and, at the same time, the expansion of the scientific influence of quantum physics and its superior ability to explain complex phenomena that were previously unexplained, led to the appearance of quantum theory in other fields of science.

If managers and their organizations want to move into a new age, they need to create a new mindset and skills based on quantum management theory. It consists of making the best decision in complex conditions and requires seven quantum skills that enable managers of organizations to think dynamically and intuitively. Management cannot be defined as influencing others to achieve specific goals, it rather should be defined as a process in which searching the goal and moving along the goal is more important and valuable than achieving the goal itself (Shelton \& Darling, 2001).

Managers realize that the only constant element of the present age equation is change. Many leaders have found that 
stability in organizations is an outdated idea and controlling and predicting is futile. Management practices are not immune to these changing assumptions about reality. Seven quantum skills are rooted in the new scientific perspective which has introduced the world as a complex, vibrant, highcommunication system rather than a machine-clock system.

These skills confront 21st century leaders with a set of brain skills for managing people and conflicts (Shelton et al., 2001). Quantum management is one of the concepts derived from quantum physics that refers to the complexity and uncertainty of phenomena. This means that the behavior of the phenomena cannot be accurately predicted. It is also possible that phenomena may occur differently in the same conditions and under the same causes each time (Lord et al., 2015).

The quantum organization is an ever-changing, adaptable borderless organization in which innovation and information flow freely. One of the reasons for the above capabilities seems to be to distance the organizational structure of this organization from the traditional hierarchical and pyramidal one.

In quantum organizations, different communication processes are used to create a shared vision and clarity of purpose (Shelton \& Darling, 2003). In the new turbulent and chaotic management world, the ultimate goal of the manager is to reach the desired point of performance or to achieve high levels of productivity (Aparicio, Gil, López, \& Díaz, 2016; García, Vegara, López, \& Díaz, 2016; Sánchez, González, López, \& Díaz, 2017; Sánchez et al., 2019; Zaragozà et al., 2019).

Productivity is a comprehensive concept that is being constantly increased as a necessity in order to promote a higher standard of living, greater prosperity, peace and comfort for all, a fundamental goal for all countries in the world, that has always been the focus of economic and government policy. Productivity is increasingly based on the knowledge, skills, and abilities of the human mind. It is a general concept of determining an organization's input-to-output ratio. To put it another way, estimating output is about consuming minimal energy, money, and time (Mohammadzadeh et al., 2013). Some experts believe that productivity is based on the idea that one can do better today than yesterday. It is a neverending effort to use human resources, skills, technology and information to achieve the best results (Hamidi, 2002). In fact, productivity is a realistic attitude to work and life and it is a measure that can continuously improve the existing situation. In addition to, productivity is the belief in human development.

The improvement and the efficient use of a variety of resources, such as labor, capital, materials, energy and information is the goal of all managers of economic organizations, industrial production units and service institutions. Proper organizational structure, efficient execution methods, professional working equipment and tools, balanced work environ- ment, and above all, qualified human resources are essential to achieve the desired productivity of managers.

Employees' participation in their affairs and their conscious efforts along with working discipline can affect productivity in a dynamic environment. The spirit of productivity improvement culture must be embodied in the body of the organization in which human resources form the central core. One of the most important goals in any organization is to improve its productivity and since human beings play a central role in productivity, their demands are key to effective organization (Hamidi, 2002).

It can be said that the main cause of stress in many cases is low productivity. Seven quantum skills can enable 21st century leaders to create a new level of organizational excellence to harness the world's most powerful energy, the energy of the mind. In order to achieve productivity in the organization, quantum reverses managers' view of phenomena from top to bottom and from inside to outside. This is possible by implementing the seven quantum skills. These skills include:

1) Quantum glance: the ability to see purposefully;

2) Quantum thinking: the ability to think in a contradictory way;

3) Quantum feeling: the ability to feel alive and well;

4) Quantum cognition: the ability to know in a creative and intuitive way;

5) Quantum action: the ability to act in a responsible manner;

6) Quantum trust: the ability to trust the process of life;

7) Quantum existence: the ability to communicate continuously

Using these seven skills, organization managers can create quantum organizations. These are places where continuous improvement and continuous learning is a cultural norm. Aforementioned seven quantum skills, do not work independently, they are displayed in an integrated set of skills (Shelton \& Darling, 2003).

The results of various studies show that factors such as management style, organizational support (Jafari \& Memarzadeh, 2017), job motivation, quality of work life (Qaderi \& Mezginejad, 2016), reward systems (Samani \& Singh, 2014), organizational culture (Al-Harbi \& Alyahya, 2013), intellectual capital (Chen et al., 2014), social capital (Porter \& Sensenbrenner, 2015), job satisfaction (Halcus \& Bousinakis, 2010) and organizational and job characteristics (Taylor et al., 2013) are related to human resource productivity.

Qasempour and Ahmadi (2015) explain that collaborative management, consulting and outsourcing management practices have significant effects on human resources productivity (Qasempour \& Ahmadi, 2015). Ghabakhloo \& Mahmoodzadeh (2016) state that management styles play a crucial role in employee productivity. Allahverdi, Farahabadi \& Sajjadi 
(2010) also mention that management styles are one of the most important factors affecting human resource productivity.

In conclusion, the main pillar of any organization is human resource management and the ultimate goal of it is to achieve maximum productivity. It is clear that knowing and applying the efficient style of management in the organization will definitely lead to maximum productivity. The present study seeks to explore the components of productivity based on the new (quantum) style of management. It aims also to analyze the indicators and to provide a practical model for the sports organizations in Iran.

\section{Methods}

\subsection{Participants}

The sample was composed of managers and staff of the Ministry of Sport and Youth of the Islamic Republic of Iran. In the first part of the study, 14 people were interviewed through thematic analysis method. In the second part, 188 people completed the questionnaire.

\subsection{Instrument}

The reliability of the interviews was assessed using test-retest reliability. The questionnaire was elaborated ad hoc and it was composed of 81 questions. The content validity of the questionnaire was evaluated by six experts and university professors. The construct validity was also evaluated and confirmed by factor analysis. Also, 20 questionnaires were distributed and evaluated during the pre-test to assess the reliability of the tool.

\subsection{Data analysis}

Data analysis was performed by WarpPLS software. After analyzing the content network, coding and screening were finally extracted into 8 main components of quantum productivity. Reliability of indices of latent variables, internal consistency and convergent and differential validity were analyzed. Capacity and predictive power of the designed model was also reported using optimum coefficient of determination (R2) and values of Stone Geyser index. Also, three fit indices, mean path coefficient $(\mathrm{APC}=0.208)$, mean $\mathrm{R} 2(\mathrm{ARS}=0.615)$ and mean variance inflation factor $(\mathrm{AVIF}=2.065)$ were confirmed.

\section{Results}

In order to evaluate the percentage of agreement within a subject used as an index of reliability of analysis, the researchers coded 3 interviews and calculated them using the following formula:
$100 \%[$ (total number of codes $) \div($ number of hits $\times 2)]=$ Percentage of internal agreement

Table 1. Reliability between the two encodings.

\begin{tabular}{ccccc}
\hline Row & $\begin{array}{c}\text { Interview } \\
\text { code }\end{array}$ & $\begin{array}{c}\text { Number } \\
\text { of codes }\end{array}$ & $\begin{array}{c}\text { Number of } \\
\text { Agreements }\end{array}$ & $\begin{array}{c}\text { Reliability between } \\
\text { the two encodings }\end{array}$ \\
\hline 1 & $\mathrm{~A}$ & 5 & 2 & $80 \%$ \\
2 & $\mathrm{~B}$ & 8 & 3 & $75 \%$ \\
3 & $\mathrm{D}$ & 8 & 3 & $75 \%$ \\
\hline Total & & 21 & 8 & $70 \%$ \\
\hline
\end{tabular}

According to Table 1, the total number of codes was 21 and the total number of agreements between these codes was 8 . The reliability of the coders for the interviews in this study was $70 \%$. Given that this reliability was greater than $61 \%$, the reliability of the coding was confirmed and it can be claimed that the reliability of the interview is appropriate.

In the next step, all interviews were coded, screened several times, and finally, 293 codes were extracted from 14 interviews. After identifying the codes, the next step involved sorting the codes and, sorting them, the summaries of coding data were identified in themes (8 components).

Table 2. Cronbach's alpha and questionnaire reliability.

\begin{tabular}{llc}
\hline Variables & Dimensions & Cronbach's alpha \\
\hline Quantum & Quantum vision & 0.741 \\
& Quantum thinking & 0.777 \\
& Quantum feeling & 0.738 \\
& Quantum cognition & 0.776 \\
& Quantum action & 0.812 \\
& Quantum trust & 0.785 \\
& Quantum existence & 0.849 \\
\hline Prganizational & Flexibility & 0.896 \\
& Reduce costs & 0.913 \\
& Quality of working life & 0.912 \\
& Organizational partnerships & 0.855 \\
& Organizational motivation & 0.844 \\
& Effective communication & 0.805 \\
& Empowerment & 0.890 \\
& Organizational commitment & 0.864 \\
\hline
\end{tabular}

WarpPLS structural equation software was used to investigate the dimensions of the research model and the impact of quantum variables on productivity in the Iranian Ministry of Sport and Youth. This software not only examines the impact of research variables, but also tests the validity and reliability of the research instrument and tests the fit of the model. 
In the WarpPLS model, the reliability of any of the indicators of current variables (structures), the internal consistency (structural reliability), as well as the convergent validity and validity are analyzed.

Table 3. Structural reliability and convergent validity of quantum skills and productivity variables.

\begin{tabular}{|c|c|c|c|c|c|c|c|c|c|c|c|c|c|c|c|}
\hline & 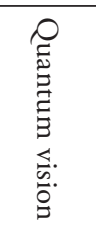 & 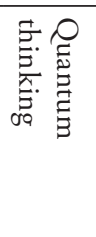 & 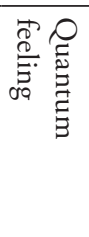 & 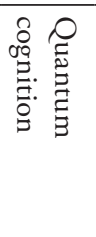 & 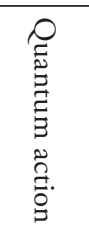 & 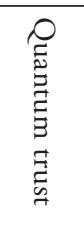 & 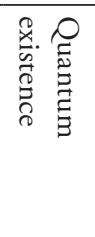 & 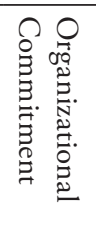 & 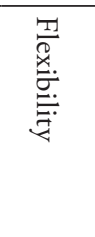 & 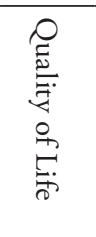 & 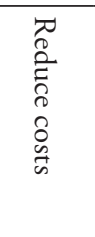 & 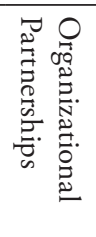 & 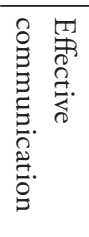 & $\begin{array}{l}\frac{T}{1} \\
3 \\
0 \\
0 \\
0 \\
0 \\
0 \\
0 \\
\end{array}$ & 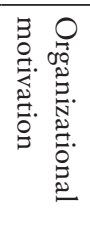 \\
\hline Combined reliability & 0.739 & 0.780 & 0.769 & 0.736 & 0.856 & 0.769 & 0.863 & 0.864 & 0.896 & 0.912 & 0.913 & 0.855 & 0.805 & 0.890 & 0.844 \\
\hline Cronbach's alpha & 0.741 & 0.777 & 0.738 & 0.776 & 0.812 & 0.785 & 0.849 & 0.800 & 0.854 & 0.883 & 0.885 & 0.795 & 0.726 & 0.853 & 0.753 \\
\hline AVE & 0.531 & 0.651 & 0.544 & 0.660 & 0.546 & 0.630 & 0.651 & 0.563 & 0.636 & 0.634 & 0.640 & 0.501 & 0.593 & 0.517 & 0.574 \\
\hline
\end{tabular}

Table 4. Differential validity of quantum skills variables.

\begin{tabular}{|c|c|c|c|c|c|c|c|c|}
\hline Structures & Structures & 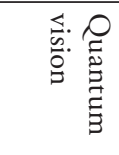 & 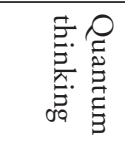 & 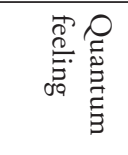 & 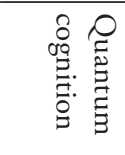 & 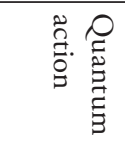 & 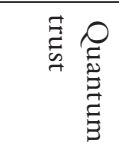 & 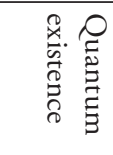 \\
\hline Quantum vision & & 0.656 & & & & & & \\
\hline Quantum thinking & & & 0.749 & & & & & \\
\hline Quantum feeling & & & & 0.587 & & & & \\
\hline Quantum cognition & & & & & 0.678 & & & \\
\hline Quantum action & & & & & & 0.667 & & \\
\hline Quantum trust & & & & & & & 0.575 & \\
\hline Quantum existence & & & & & & & & 0.593 \\
\hline
\end{tabular}

Table 5. Differential validity of quantum productivity variables.

\begin{tabular}{|c|c|c|c|c|c|c|c|c|}
\hline Structures & 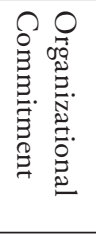 & 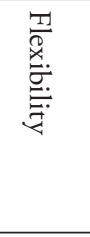 & 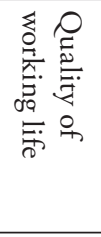 & $\begin{array}{l}\text { त्र } \\
0 \\
\text { हे } \\
0 \\
0 \\
0 \\
0 \\
\omega\end{array}$ & 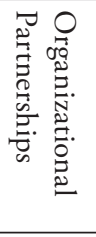 & 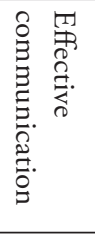 & $\begin{array}{l}\text { T1 } \\
3 \\
0 \\
0 \\
\vdots \\
0 \\
\vdots \\
0 \\
0\end{array}$ & 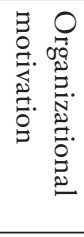 \\
\hline Organizational Commitment & 0.750 & & & & & & & \\
\hline Flexibility & & 0.797 & & & & & & \\
\hline Quality of working life & & & 0.797 & & & & & \\
\hline Reduce costs & & & & 0.800 & & & & \\
\hline Organizational Partnerships & & & & & 0.708 & & & \\
\hline Effective communication & & & & & & 0.627 & & \\
\hline Empowerment & & & & & & & 0.719 & \\
\hline Organizational motivation & & & & & & & & 0.758 \\
\hline
\end{tabular}




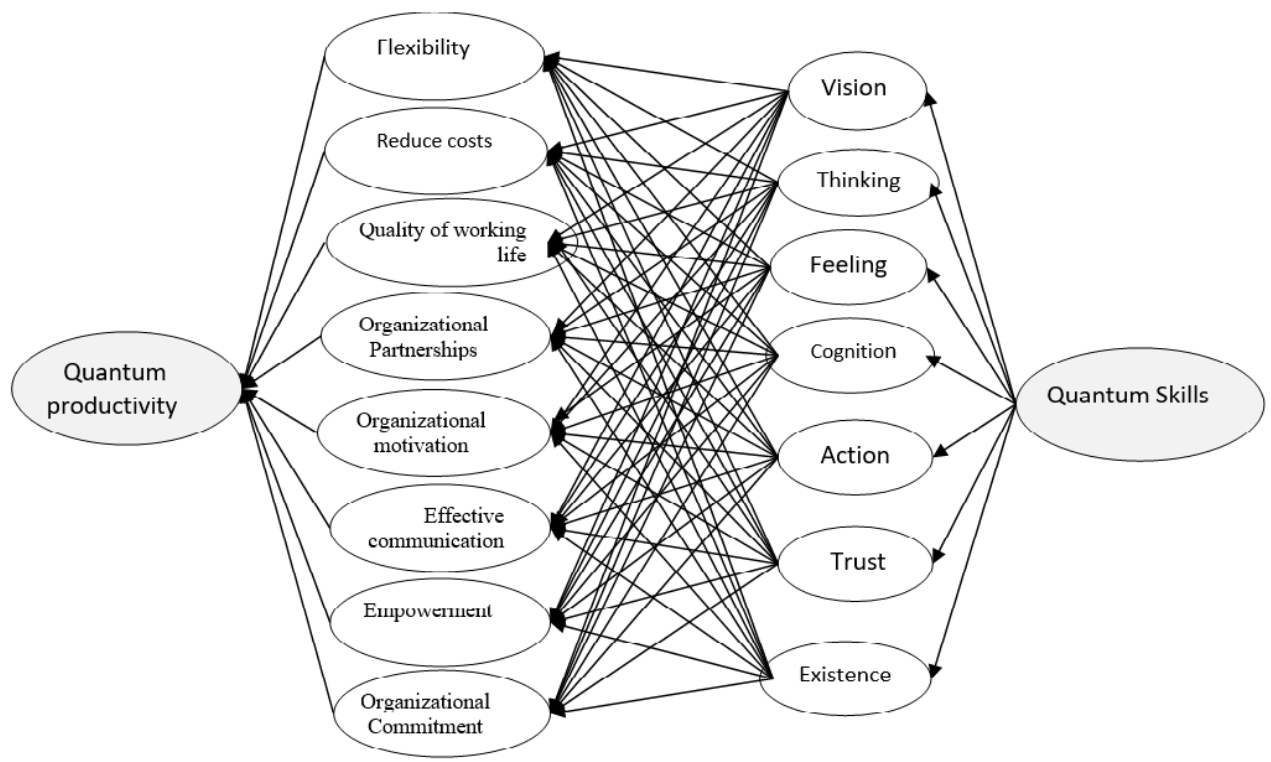

Figure 1. Conceptual model of research.

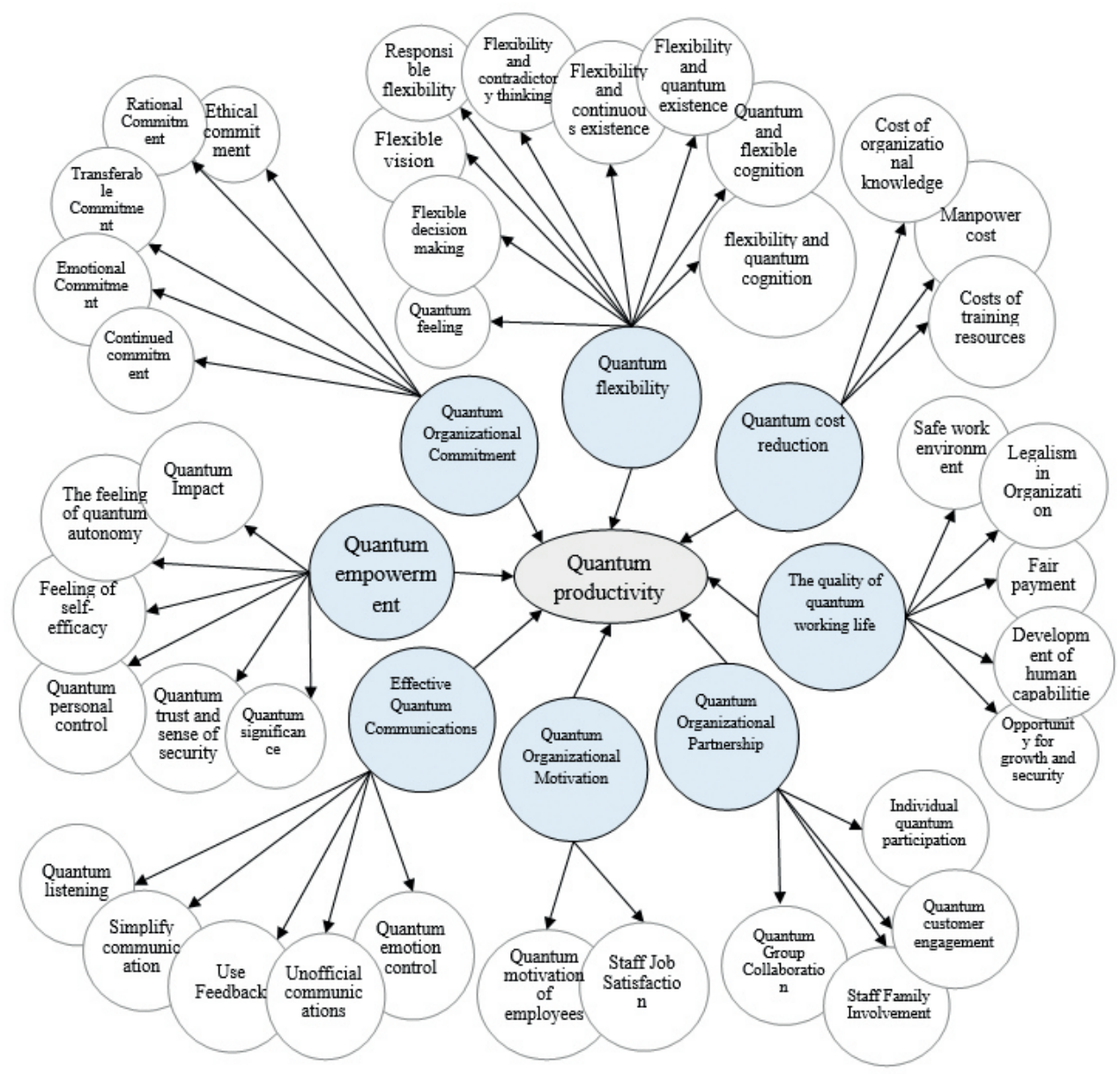

Figure 2. Qualitative model (interview) and extracted themes and indicators. 
There were 17 variables in the research model. The components of quantum skills are independent variables and the variables of organizational productivity are dependent variables.

In the first step, we investigated the effect of quantum vision on the model. The effect of quantum visibility skill in organization on organizational productivity components was significant $(\mathrm{p}<0.05)$. According to the results, quantum vision had the greatest impact on increasing the level of organizational commitment of employees, however, the coefficients of influence of other assumptions were also significant, indicating the high impact of quantum vision on increasing levels of organizational productivity. The lowest impact factor referred to the impact of quantum vision on the reduction of organizational cost versus the impact of quantum vision on other components of organizational productivity. Therefore, given the impact of quantum vision on organizational productivity components, it is expected that managers of the organization will pay attention to the important role of quantum vision in enhancing organizational productivity.

Quantum thinking also had the greatest impact on increasing the level of organizational motivation of employees. Despite the impact of quantum thinking on productivity components, its impact on organization productivity com- ponents was less than quantum visibility in the organization, and quantum thinking had the most impact on organizational motivation and organizational participation. Interestingly, the impact of quantum thinking on employee motivation and participation was higher than the impact of quantum vision on participation and motivation and so, it is important to focus on quantum thinking to increase motivation and participation. The findings showed that the quantum sense had the greatest effect on increasing the level of organizational communication among employees. In examining the impact of quantum emotion, its place in enhancing organizational communication was important. Also, quantum cognition had the greatest impact on increasing levels of cost reduction, commitment, and organizational flexibility. According to the data obtained from the data analysis, quantum practice had the greatest impact on increasing the flexibility and organizational motivation of employees and had the least impact on the level of employee organizational participation. Also, quantum trust had the greatest impact on enhancing organizational commitment and least impact on the level of employee organizational participation. The quantum impact also had the greatest impact on enhancing employee engagement and organizational commitment in the organization.

Table 6. Impact of quantum skills on the quantum productivity dimensions.

\begin{tabular}{llcrc}
\hline Number & Hypotheses & Path coefficient & Significance & Result \\
\hline 1 & Quantum skills have a significant impact on organizational commitment. & 0.650 & $<0.001$ & Confirmation \\
2 & Quantum skills have a significant impact on organizational flexibility. & 0.462 & $<0.001$ & Confirmation \\
3 & Quantum skills have a significant impact on organizational quality. & 0.473 & $<0.001$ & Confirmation \\
4 & Quantum skills have a significant impact on reducing organizational costs. & 0.383 & $<0.001$ & Confirmation \\
5 & Quantum skills have a significant impact on organizational participation. & 0.578 & $<0.001$ & Confirmation \\
6 & Quantum skills have a significant impact on organizational motivation. & 0.335 & $<0.005$ & Confirmation \\
7 & Quantum skills have a significant impact on organizational communication. & 0.519 & $<0.001$ & Confirmation \\
8 & Quantum skills have a significant impact on organizational empowerment. & 0.306 & $<0.009$ & Confirmation \\
\hline
\end{tabular}

The higher the coefficients obtained, the greater the effect of the variable in question. In the obtained structural model, as it has been shown, the significant value of each of the main research hypotheses and the obtained coefficient of impact were acceptable.

The reliability of any of the currently variable indices in the WarpPLS model was determined by the amount of factor loadings of each index. The value of each of the operating loads of the currently relevant variable indices should be greater than or equal to 0.5 . 
Table 7. Value of operational loads indicators of quantum skill components and productivity

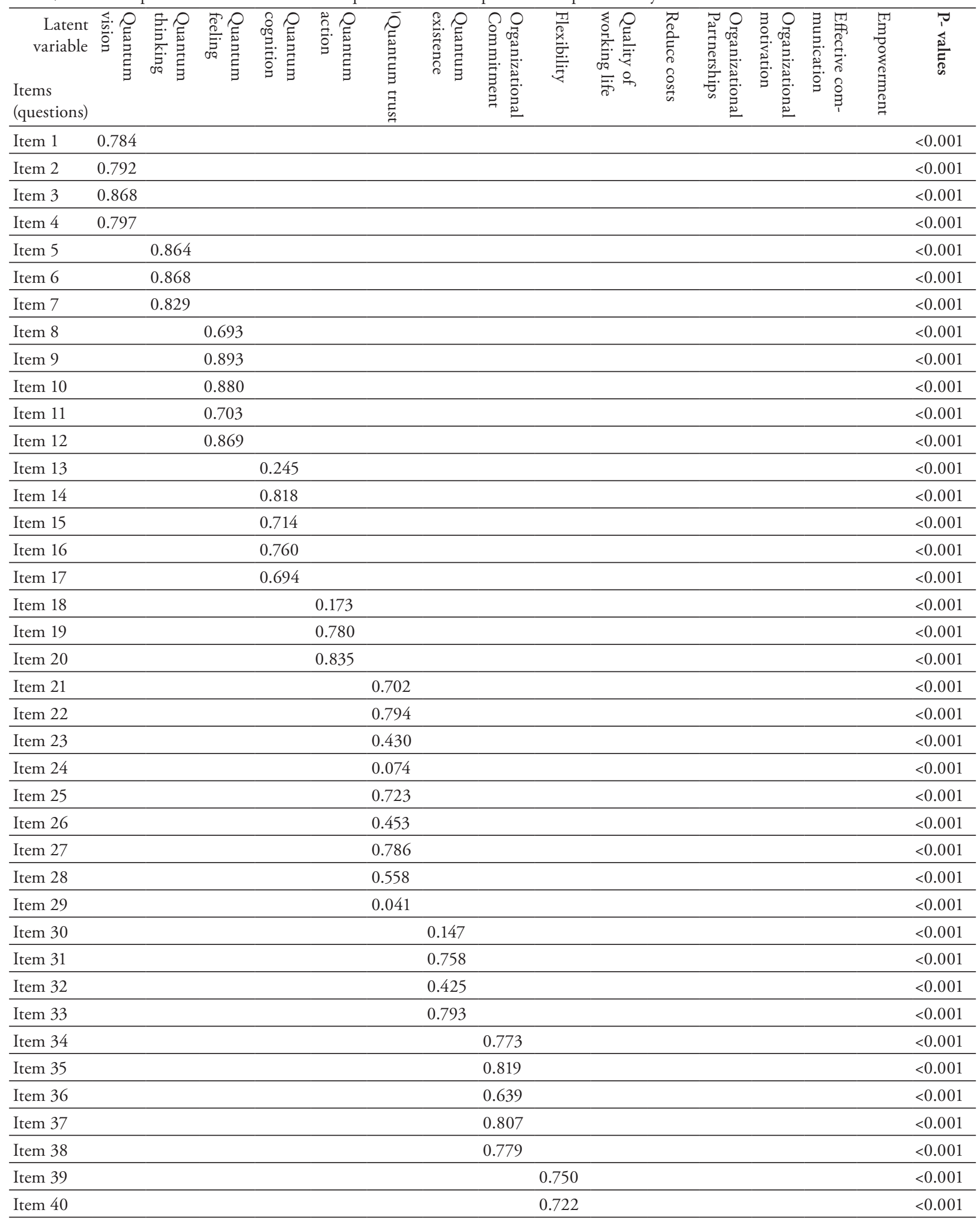




\begin{tabular}{|c|c|c|c|c|c|c|c|c|c|c|c|c|c|c|c|}
\hline $\begin{array}{r}\text { Latent } \\
\text { variable } \\
\text { Items } \\
\text { (questions) }\end{array}$ & 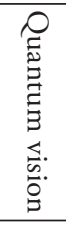 & 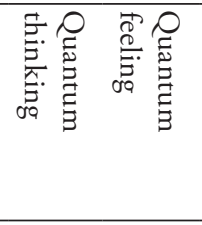 & 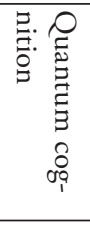 & 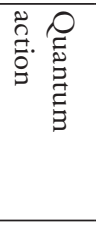 & 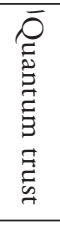 & 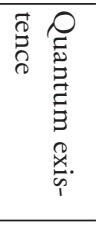 & 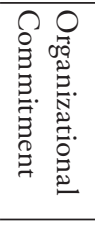 & 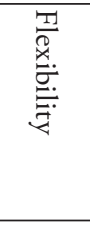 & 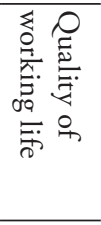 & 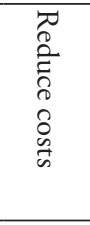 & 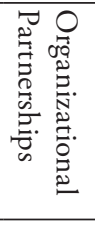 & 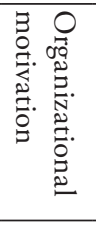 & 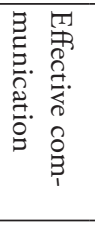 & 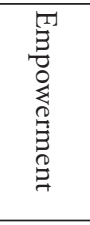 & 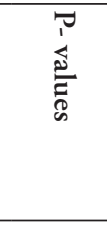 \\
\hline Item 41 & & & & & & & & 0.732 & & & & & & & $<0.001$ \\
\hline Item 42 & & & & & & & & 0.892 & & & & & & & $<0.001$ \\
\hline Item 43 & & & & & & & & 0.870 & & & & & & & $<0.001$ \\
\hline Item 44 & & & & & & & & & 0.713 & & & & & & $<0.001$ \\
\hline Item 45 & & & & & & & & & 0.901 & & & & & & $<0.001$ \\
\hline Item 46 & & & & & & & & & 0.842 & & & & & & $<0.001$ \\
\hline Item 47 & & & & & & & & & 0.782 & & & & & & $<0.001$ \\
\hline Item 48 & & & & & & & & & 0.724 & & & & & & $<0.001$ \\
\hline Item 49 & & & & & & & & & 0.801 & & & & & & $<0.001$ \\
\hline Item 50 & & & & & & & & & & 0.834 & & & & & $<0.001$ \\
\hline Item 51 & & & & & & & & & & 0.868 & & & & & $<0.001$ \\
\hline Item 52 & & & & & & & & & & 0.809 & & & & & $<0.001$ \\
\hline Item 53 & & & & & & & & & & 0.875 & & & & & $<0.001$ \\
\hline Item 54 & & & & & & & & & & 0.639 & & & & & $<0.001$ \\
\hline Item 55 & & & & & & & & & & 0.749 & & & & & $<0.001$ \\
\hline Item 56 & & & & & & & & & & & 0.741 & & & & $<0.001$ \\
\hline Item 57 & & & & & & & & & & & 0.751 & & & & $<0.001$ \\
\hline Item 58 & & & & & & & & & & & 0.751 & & & & $<0.001$ \\
\hline Item 59 & & & & & & & & & & & 0.648 & & & & $<0.001$ \\
\hline Item 60 & & & & & & & & & & & 0.839 & & & & $<0.001$ \\
\hline Item 61 & & & & & & & & & & & 0.701 & & & & $<0.001$ \\
\hline Item 62 & & & & & & & & & & & & 0.715 & & & $<0.001$ \\
\hline Item 63 & & & & & & & & & & & & 0.898 & & & $<0.001$ \\
\hline Item 64 & & & & & & & & & & & & 0.827 & & & $<0.001$ \\
\hline Item 65 & & & & & & & & & & & & 0.846 & & & $<0.001$ \\
\hline Item 66 & & & & & & & & & & & & & 0.866 & & $<0.001$ \\
\hline Item 67 & & & & & & & & & & & & & 0.812 & & $<0.001$ \\
\hline Item 68 & & & & & & & & & & & & & 0.773 & & $<0.001$ \\
\hline Item 69 & & & & & & & & & & & & & 0.820 & & $<0.001$ \\
\hline Item 70 & & & & & & & & & & & & & 0.851 & & $<0.001$ \\
\hline Item 71 & & & & & & & & & & & & & 0.886 & & $<0.001$ \\
\hline Item 72 & & & & & & & & & & & & & 0.813 & & $<0.001$ \\
\hline Item 73 & & & & & & & & & & & & & 0.802 & & $<0.001$ \\
\hline Item 74 & & & & & & & & & & & & & & 0.847 & $<0.001$ \\
\hline Item 75 & & & & & & & & & & & & & & 0.861 & $<0.001$ \\
\hline Item 76 & & & & & & & & & & & & & & 0.844 & $<0.001$ \\
\hline Item 77 & & & & & & & & & & & & & & 0.781 & $<0.001$ \\
\hline Item 78 & & & & & & & & & & & & & & 0.817 & $<0.001$ \\
\hline Item 79 & & & & & & & & & & & & & & 0.872 & $<0.001$ \\
\hline Item 80 & & & & & & & & & & & & & & 0.859 & $<0.001$ \\
\hline Item 81 & & & & & & & & & & & & & & 0.766 & $<0.001$ \\
\hline
\end{tabular}


Confirmatory factor analysis showed that, according to Kock (2012), the measurement model had sufficient reliability in terms of indices.

Factor loads were also used to examine the convergent validity of the research instrument. To prove that the research instrument has convergent validity, two criteria must be met. First, the probability values should be lower than 0.05 and, second, the values of the relevant operating loads should be higher than or equal to 0.5 . Since both criteria for the present research instrument were fulfilled, therefore, the research questionnaire has appropriate convergent validity.

The prediction power of the designed model was analyzed using the coefficient of determination (R2) for the dependent variables. In the present study, considering the table values, it can be concluded that the structural model of the present study has sufficient predictive power.

Table 8. Coefficients for determining dependent variables.

\begin{tabular}{|c|c|c|}
\hline Dependent variables & $\mathrm{R}^{2}$ & $\mathrm{Q}^{2}$ \\
\hline Organizational Commitment & 0.782 & 0.620 \\
\hline Flexibility & 0.501 & 0.693 \\
\hline Quality of working life & 0.532 & 0.709 \\
\hline Reduce costs & 0.726 & 0.723 \\
\hline Organizational Partnerships & 0.395 & 0.674 \\
\hline Organizational motivation & 0.320 & 0.627 \\
\hline Effective communication & 0.562 & 0.730 \\
\hline Empowerment & 0.390 & 0.525 \\
\hline
\end{tabular}

Finally, it is appropriate to complete the analysis of the structural model estimated by PLS technique using the Stone-Geyser (Q2) test. Q2 values are usually close to R2. However, unlike R2 coefficients, Q2 coefficients can also produce negative values (Kock, 2012). In the present study, the values of the StoneGeyser test were calculated above zero, indicating that the model considered has the capacity and predictive power required.

With regard to the structural model analysis, it can be seen that all of the indices considered had the necessary conditions and therefore this model has sufficient predictive power. After reviewing and analyzing the measurement model and structural model, the goodness of fit indices was discussed.

The software used in the research (WarpPLS) offers three fitting indices: average path coefficient (APC), average R2 (ARS) and average variance inflation factor (AVIF).

Table 9. Model fit indices.

\begin{tabular}{lcc}
\hline Index & Value & P-value \\
\hline Average Path Coefficient (APC) & 0.208 & 0.029 \\
Average R2 (ARS) & 0.615 & $<0.001$ \\
Average Variance Inflation Factor (AVIF) & 2.065 & --- \\
\hline
\end{tabular}

As shown in the table, the probability value for APC and ARS was lower than 0.05 , so the model is well-suited for this. Also, in terms of AVIF index, given that its value is less than 5, the model has good fit.

\section{Discussion}

The results show that quantum visibility skills in organization have an impact on organizational productivity components. The quantum view of conscious observation is based on the assumption that reality is inherently subjective and that what is seen in the outside world is a function of internal assumptions and beliefs. This skill enables managers to be more aware of their intentions. Clear intentions play an important role in transforming an ordinary organization into a learning organization. A manager who is capable of quantum visualization is modeling his ability to define and test assumptions and beliefs. If the staffs of sports organizations are not involved, they will probably not be able to perceive, so they will not be able to create new opportunities. In that case, they still cling to their mental imagination and cannot make the choices they need to succeed.

The results indicate that quantum thinking skills affect the components of organizational productivity. Despite the impact of quantum thinking on the productivity components, its impact on the productivity components of the organization is lower than quantum visibility in the organization.

Therefore, it is important to pay attention to quantum thinking in order to increase motivation and participation. Quantum thinking is the ability to think in a contradictory way. Many of the key organizational issues are based on inconsistent questions that are not simply answered through rational and linear decision-making processes. The ability to think in a contradictory way shows that the world often acts in an irrational and contradictory way. Conflict resolution is also a contradictory process. Often one side views a solution as desirable, while the other party thinks the opposite. These contradictory ideas have made difficult the win-win solutions. The flow of quantum thinking skills generates a great deal of creativity and often irrational thinking that allows managers to go beyond the bounds of binary thinking. The ability of the organization to thrive and perhaps even survive requires the recognition and development of this skill.

According to the results the effect of quantum sensation on the components of organizational productivity is significant. The impact of quantum emotion in enhancing organizational communication is also important. The ability to feel quantum enables managers to feel good internally, no matter what happens outside. Quantum emotion is the ability to feel alive, based on the logic that humans face the same quantum as other worlds and are therefore subject to the universal rules of energy stimulation (in which negative emotions capture 
energy and positive emotions are energetic). Despite the fact that these rules are known, science does not seem to reduce the amount of stress and conflict that is prevalent in the business world. Empowering employees and executives in a vibrant working process enables people to feel good inside, this leads to an increase in the productivity of individuals and ultimately to the organization.

As per the results reported in this paper, quantum cognition skills in the organization influence the components of organizational productivity. Quantum cognition is not a tool to put an end to the hard work and effort, it rather serves to reduce the repetitive processes in the organization. Managers who find quantum skills useful, not only treat people in a respectful and deeply intuitive way, but also they create an atmosphere of awareness and thinking. However, much of the existing information need to be discovered by the managers and they need to learn how to use them in managing new ways of knowing. It is easy to see that information is much more than can be processed in traditional and analytical ways. Quantum knowledge refers to the ability to know in a creative and intuitive way. In this case, it consists of paying more attention and helping employees and managers in the organization to know their tasks better and strive to improve their performance. The results show that the impact of quantum practice in the organization affects the components of organizational productivity. Quantum action is the ability to act for the whole set. Managers can use this skill to design goals that are useful to both themselves and the larger system. Quantum practice is: Ability to act with a sense of belonging to the whole, the whole organization, the whole community and the entire cosmic system. Everything in this world is part of a whole complex solidarity, with each sector affecting the other. This inseparable quantum principle created a new development in conflict. The skill of quantum action can be used to design flawless deeds, creatures whose intentions are good, both for themselves and for the larger system. Managers' thinking affects the whole system (e.g. team, department, organization and world). Therefore, if the manager wants the staff to collaborate in the development of a new way of seeing and responding to conflict, the manager must begin by modeling this new perspective.

Quantum trust is the ability to trust the process of life. If managers want credible self-organization, they should be willing to temporarily step into the chaos. This concept also refers to the interdependence of organizational interactions and when this correlation is increased, it will lead to an increase in the level of productivity in the organization and managers and staff will have better reactions to each other.

Quantum presence in the organization affects the components of organizational productivity. Quantum existence is the ability to communicate continuously. This skill enables managers to own emotions rather than attribute them to others. This quantum skill dimension, given its impact, leads to increased levels of productivity in the organization. Quantum relation - that is, the ability to conceptually connect with others in a way that anyone can see the world through another's eyes - is a prerequisite for conflict resolution. When managers view all of their communications as criterion of accuracy and vulnerability, they model a new way of communicating with their surroundings. This skill is the ability to get into relationships. At the very small level, the concept of existence only finds meaning in relationships. Managers who use this skill have found that all relationships are great learning opportunities, and none of them happen without a reason. Managers should use this quantum skill to create an environment where people can interact with each other openly and vertically, without fear of punishment.

In their study, Khoshtinat, Farahani \& Salimi (2017) conclude that quantum sensing skills, quantum cognition and bio-quantum influence managers' productivity. Shelton \& Darling (2001) state that quantum thinking is a prerequisite for innovative strategies in the organization. In this regard, Azimi Sanavi (2017) also states that: "If quantum thinking dominates the organization, the environment will be more dynamic and more creative and the consequence of this will be to increase the productivity of the human resources in the organization". Salimi, Rajaeepour, Siadat \& Bidram (2016) add that managers with quantum skills allow a greater employee engagement and use their opinions and experiences as effective decision makers. According to the results of the present study and the results of studies conducted in this field it can be concluded that: the quantum theory of management is a quantum metaphor and it serves to enhance the effectiveness of managers that change their way of thinking from machine-driven and algebraic to dynamic, creative and effective (Azimi Sanavi, \& Razavi Seyyed, 2015). In the quantum perspective, every organization is based on a small world and contrary to previous and classical theories that believed in hierarchical structure, the emphasis is on interaction, cooperation, equality, communication, mutual benefit, harmony, and expansiveness (Nazari and Khosravi, 2017).

Quantum gaze skills are a prerequisite for implementing an organizational vision and quantum cognition and quantum thinking skills are a prerequisite for innovative strategies in the organization. Quantum feeling and quantum trust are the desired skills for organizational collaborative structures. Quantum practice skills enable employees to instill shared values in their personal relationships (Shelton \& Darling, 2001). Quantum management skills serve to enhance the power and effectiveness of managers and employees that offer an open, creative and dynamic approach. Therefore, the organization that puts quantum management on its agenda is an opportunity for capable employees who, in addition to innovation and creativity, can be effective in team building 
and helping other employees (Sodagar et al., 2016). Finally, Nazari and Khosravi (2017) state that quantum management provides the basis for reciprocal interaction, collaboration, and communication.

\section{References}

1. Al-harbi, M. A., \& Alyahya, M. S. (2013). Impact of organizational culture on employee performance. International review of Management and Business Research, 2(1), 168-175.

2. Allahverdi, M., Farahabadi, E., Sajadi, H. (2011). Prioritizing factors effecting on human resources productivity: Viewing of middle class managers in Isfahan University of Medical Sciences. JHOSP, 9(3-4), 77-85. )In Persian).

3. Aparicio Sarmiento, A., Gil López, M. I., López Sánchez, G. F., \& Díaz Suárez, A. (2016). Satisfacción de usuarios de dos clubes de pádel de Cartagena (Región de Murcia). SPORT TK-Revista EuroAmericana de Ciencias del Deporte, 5(2), 27-32. doi: 10.6018/264611

4. Azimi Sanavi, B. (2017). Investigating the relationship between quantum thinking approach and creativity and organizational productivity (Case study, selected non-profit institutions of Mashhad metropolis). Third International Conference on Entrepreneurship, Creativity and Innovation, Shiraz, Iran. )In Persian).

5. Azimi Sanavi, B., \& Razavi Seyyed, M. H. (2015). Investigating the level of familiarity and application of quantum skills in sports organizations of the country. JSM, Tehran University. 6(4), 613-625.

6. Chen, J., Zhuhai, Z., \& Hong Yuan, X. (2014). Measuring intellectual capital: A new model and empirical study. Journal of Intellectual Capital, 5(1), 195-212.

7. García Mayor, J., Vegara Ferri, J. M., López Sánchez, G. F., \& Díaz Suárez, A. (2016). Satisfaction of sports services users in Orihuela (Alicante). SPORT TK-Revista Euroamericana de Ciencias del Deporte, 5(1), 155-162. doi: 10.6018/254161

8. Ghaderi, N., \& Mezginejad, S. (2016). Relationship between job motivation and quality of work life with the productivity of human resources of agricultural bank employees in South Khorasan. International Conference of Management and Accounting, Tehran, Iran. )in Persian).

9. Ghasempour, A., \& Ahmadi, M. A. (2015). The study of coordination of management style with employee maturity and its impact on their performance (productivity). First International Conference on Management and Entrepreneurship, Tehran, Iran. )In Persian).

10. Ghobakhllo, M., \& Mahmoud Zadeh, M. (2016). The relationship between management styles and employee productivity (Case study: Saderat Bank, Tehran City). Third International Conference on Advanced Research in Management, Economics and Humanities. )In Persian).

11. Halkos, G., \& Bousinakis, D. (2010). The effect of stress and satisfaction on productivity. International Journal of Productivity and Performance Management, 59(5), 415-431.

12. Hamidi, M. (2002). Promoting Productivity in the Physical Education of Education. The first international congress on physical education and sports of female students. (In Persian).

13. Jafari, A., \& Memarzadeh, G. (2017). Identification of effective factors on employee productivity in a military health organization. Journal of Military Medicine, 19(3), 234-244. )In Persian).

14. Khosh Tinat, B., Farahani, T., \& Salimi, R. (2017). Investigating the effect of the quantum skills of managers on increasing the productivity of the organization's employees (Case study, National Bank Branches of Guilan Province). Fourth Conference on Applied Economics and Management with a National Approach, Babolsar, Iran. )In Persian).

15. Kock, N. (2012). Using WarpPLS in e-collaboration studies: Mediating effects, control and second order variables, and algorithm choices. International Journal of e-Collaboration, 7(3), 1-13.

16. Lord, R. G., Dinh, J. E., \& Hoffman, E. L. (2015). A quantum approach to time and organizational change. Academy of Management Review, 40(2), 263-290.

17. Mohammadzadeh, P., Akbari Fard, H., Akbari, A., \& Atapour, S. (2013). Productivity and economic growth in selected developing countries. Productivity Management Journal, 6(24),15-33.

18. Nazari, R., \& Khosravi, S. (2017). Modeling effect of communication skills on quantum management and its role on organizational agility: A case study of Isfahan sport organizations. Journal of Human Resource Management in Sport, 4(1), 61-70. )In Persian).

19. Portes, A., \& Sensenbrenner J. (2015). Embeddedness and immigration: Notes on the social determinants of economic action. American Journal of Sociology, 98, 1320-1350.

20. Salimi, M. H., Rajaeepour, S., Siyadat, S. A., \& Bidram, H. (2016). The Relation between quantum management skills and organizational agility capabilities with the mediating role of organizational intelligence in the selected state-universities of Isfahan. Journal Management System, 9(33), 113-138. )In Persian).

21. Samani, A. K., \& Singh, P. (2014). Performance-enhancing compensation practices and employee productivity: The role of workplace bullying. Human Resource Management Review, 24(1), 5-16.

22. Sánchez García, C., González Carcelén, C., López Sánchez, G. F., \& Díaz Suárez, A. (2017). Satisfacción de clientes externos. Estudio de caso de una piscina cubierta. SPORT TK-Revista EuroAmericana de Ciencias del Deporte, 6(2), 81-88. doi: 10.6018/300421

23. Sánchez Miguel, R., Navarro Guillén, J., Alfaro Royo, M. C., Cárdenas Beltrán, C. N., Fernández Alquézar, O., \& Zaragozà Biot, M. C. (2019). Qualitative study on mental health care in the Moroccan immigrant collective. Atena Journal of Public Health, 1(5), 1-12.

24. Shelton, C. K., \& Darling, J. R. (2001). The quantum skills model in management: A new paradigm to enhance effective leadership. Leadership \& Organization Development Journal, 22(6), 264-273.

25. Shelton, C., \& Darling, J. R. (2003). From theory to practice: Using new science concepts to create learning organization. Journal of Learning Organization, 10(6), 353-360.

26. Shelton, C., Hall, R. F., \& Darling, J. R. (2003). When cultures collide: The challenge of global integration. European Business Review, 15(5), 312-323.

27. Sodagar, H. R., \& Jabari, N., Suleiman Pouraman, M., \& Lotfi, N. (2016). The role of capable managers in applying quantum skills in organizations. Fourth International Conference on Applied Research in Management and Accounting, Tehran, Iran. )In Persian).

28. Taylor, J., Steel, B. S., \& Simon, C. A. (2013). The influence of job attributes and culture on job productivity comparing the views of public servants in Asia Pacific and the United States. Review of Public Personnel Administration, 33(2), 205-224.

29. Zaragozà Biot, M. C., Navarro Guillén, J., Sánchez Miguel, R., Cárdenas Beltrán, C. N., Fernández Alquézar, O., \& Alfaro Royo, M. C. (2019). Nursing care in adult patients with extracorporeal membrane oxygenation (ECMO). Systematic review. Atena Journal of Public Health, 1(2), 1-18. 